\title{
Er cytostatika skadelig for hjernen?
}

\author{
Enkelte kreftpasienter klager over svekket hukommelse og konsentrasjonsevne etter behandling med \\ cytostatika. Plagene kan være forbigående eller varige. Sammenhengen mellom subjektive plager, nevro- \\ psykologiske funn og funksjonell bildediagnostikk er uklar.
}

\section{Marie Østby-Deglum}

maust10@student.sdu.dk

Alv A. Dahl

Mange leger vil møte pasienter som har fått cytostatika mot kreft, og noen av pasientene vil fortelle at de har plager de mener er varige bivirkninger. I de senere år har det vært mye oppmerksomhet rundt den mulige effekten cytostatika kan ha på kognitive funksjoner, slik som hukommelse, konsentrasjonsevne og planleggingsevne. Dette er et relativt ferskt og vanskelig forskningsfelt, og resultater av de studiene som er gjort, kan være vanskelige å tolke.

\section{Subjektiv kognitiv dysfunksjon}

Å glemme ting man husket før, ha vansker med å konsentrere seg, finne riktig ord på ting og følge med i en samtale sammen med økt trettbarhet betegnes gjerne som subjektiv kognitiv dysfunksjon. En del kvinner som har gjennomført cytostatikabehandling mot brystkreft, vil ha slike plager, men forekomsten varierer mye mellom ulike studier - fra $25 \%$ til $83 \%$ (1). Noen, men ikke alle studier viser høyere forekomst enn hos friske kontrollpersoner, og plager er assosiert med angst, depresjon og tretthetsfornemmelse (fatigue) både før og etter behandling. I en studie av kvinner med brystkreft var forekomsten av subjektiv kognitiv dysfunksjon før starten på cytostatikabehandling hele $23 \%$ (2).

Hukommelses- og konsentrasjonsproblemer før cytostatika- og/eller strålebehandling er også vanlig ved andre kreftformer, også blant menn (3). I en prospektiv studie med nesten 600 kreftpasienter av begge kjønn gikk andelen med slike plager opp etter gjennomført behandling og sank så etter seks måneder, men uten at nivået før behandling ble nådd (3). Andelen var høyere etter cytostatikabehandling enn etter stråleterapi og høyere blant kvinner enn blant menn.

De første målinger av subjektiv kognitiv funksjon ved kreft skjer ofte på et tidspunkt da pasienten er under stress fra en fersk kreftdiagnose. Dette er et betydelig metodeproblem. Mange pasienter har lest om behandlingen de skal få, blant annet på Internett, og kan være preget av en forventing om bivirkninger.

\section{Objektiv kognitiv dysfunksjon}

Hukommelse, abstrakt tenkning, språkfunksjoner og evnen til å strukturere, planlegge, gjennomføre og kontrollere sammensatte handlinger er kompliserte kognitive funksjoner. Svikt i disse funksjonene kan oppfattes og rapporteres som subjektive plager, men de kan også måles objektivt ved nevropsykologiske tester, som settes sammen $i$ testkombinasjoner (testbatterier) etter hvilke funksjoner man ønsker å vurdere. Testing gjennomføres av kvalifisert psykolog, og pasientens svar vurderes ved hjelp av normdata basert på kjønn, alder og sosial kontekst.

Studier med bruk av nevropsykologiske tester har vist økt forekomst av kognitiv funksjonsreduksjon etter allogen stamcelletransplantasjon (4) og brystkreft (5) flere år etter behandlingen. Slike testmetoder er ikke problemfrie, særlig ved måling av individuelle endringer over tid (6). De fleste av testene har også svak sammenheng med dagliglivets problemer (7). Det er også dårlig overensstemmelse mellom subjektiv og objektiv kognitiv dysfunksjon, noe som er vanskelig å forklare. Men dette kan få alvorlige følger for enkeltpasienter dersom det blir brukt for å presse pasienter med betydelige subjektive plager, men med minimale funn ved tester, ut $i$ arbeidslivet etter gjennomført kreftbehandling.

Studier blant menn med testikkelkreft er særlig interessante, fordi pasientene er unge og uten aldersbetinget kognitiv reduksjon, og fordi mange av dem ikke får cytostatikabehandling initialt. I en norsk studie med slike pasienter var det ingen signifikant forskjell i de nevropsykologiske testresultatene mellom dem som hadde fått og dem som ikke hadde fått cytostatika (8).

Funksjonell bildediagnostikk gir en visualisering av hjernens metabolske aktivitet mens testpersonen gjennomgår nevropsykologisk testing. I en studie med kvinner som hadde gjennomført cytostatika- behandling mot brystkreft ti år tidligere, var den metabolske aktivering i relevante hjerneområder for planlegging og visuell hukommelse under nevropsykologisk testing, lavere enn blant friske kvinner (9). Andre studier har vist langvarig reduksjon av aktiviteten i hjerneområder relevante for høyere kognitive funksjoner, men sammenhengen mellom subjektive plager, testresultater og funn ved funksjonell bildediagnostikk er ofte uklar (10).

\section{Andre forhold av betydning}

Dyreforsøk tyder ikke på at noen cytostatikatyper gir mer kognitive problemer enn andre (11). Det er heller ikke påvist sammenheng mellom hvilke ledningsbaner som skades og type cellegift. Studier har også vist kognitive problemer ved bruk av tamoksifen, som gis som tilleggsbehandling ved østrogenreseptorpositive former for brystkreft (12). Det er usikkert om dette også gjelder for nyere aromatasehemmere (13). Bruken av slike midler induserer menopause hos yngre kvinner, og menopause i seg selv er forbundet med lærings- og hukommelsesproblemer av forbigående art (14).

Kognitiv reduksjon kan skyldes mange andre forhold enn cytostatikabehandling. Dette gjør det vanskelig å fastslå betydningen av cytostatika for seg. Hukommelsestrening og fysisk aktivitet har dokumentert effekt mot kognitiv dysfunksjon (15), men dette er ikke klart vist hos kreftpasienter etter cytostatikabehandling $(16,17)$.

\section{Hvilke råd bør gis?}

Mange kreftpasienter får subjektive kognitive plager etter cytostatikabehandling, de fleste forbigående, men noen varig. Dette tilsier etter vårt skjønn at nevropsykologisk utredning ikke bør iverksettes før tidligst ett år etter at denne behandlingen er avsluttet. Inntil da bør pasientene forklares at sjansen for spontan bedring er god. Vansker med hukommelse og konsentrasjon må tas på alvor og ikke avvises med at pasienten skal være glad for den vellykkede kreftbehandlingen. Kreftomsorgen bør søke samarbeid med andre spesialiteter med kompetanse på kognitiv dysfunksjon, slik som nevrologi, geriatri og alderspsykiatri. 


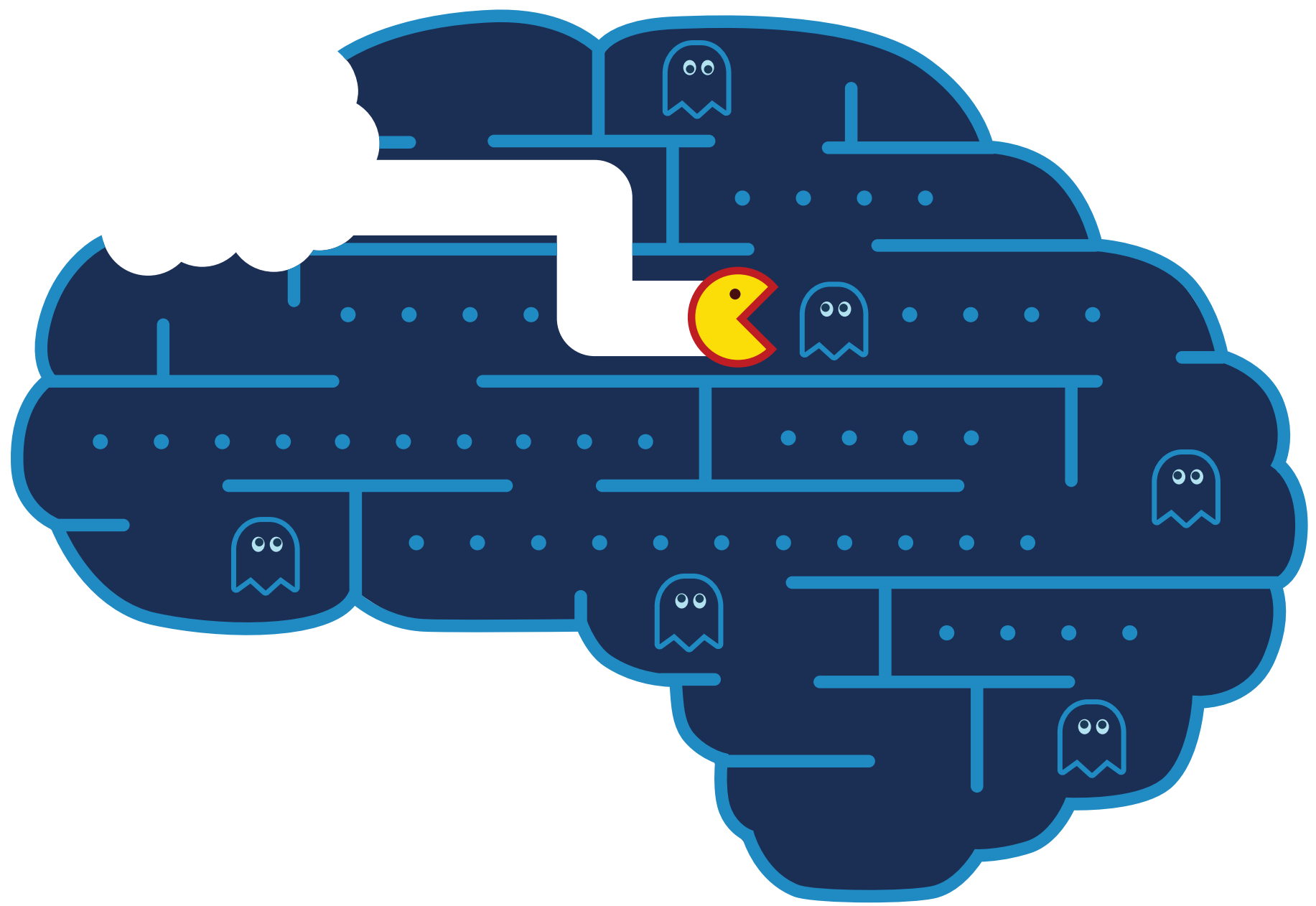

Illustrasjon @ Stein Løken

\section{Marie Østby-Deglum (f. 1989)}

er medisinstudent ved Syddansk universitet, Odense.

Forfatter har fylt ut ICMJE-skjemaet og oppgir ingen interessekonflikter.

\section{Alv A. Dahl (f. 1944)}

er forskningsrådgiver for psykososial onkologi, Oslo universitetssykehus, Radiumhospitalet. Forfatter har fylt ut ICMJE-skjemaet og oppgir ingen interessekonflikter.

\section{Litteratur}

. Pullens MJ, De Vries J, Roukema JA. Subjective cognitive dysfunction in breast cancer patients: a systematic review. Psychooncology 2010; 19: $1127-38$

2. Jansen CE, Cooper BA, Dodd MJ et al. A prospective longitudinal study of chemotherapy-induced cognitive changes in breast cancer patients. Support Care Cancer 2011: 19: 1647-56.

3. Kohli S, Griggs JJ, Roscoe JA et al. Self-reported cognitive impairment in patients with cancer. J Oncol Pract 2007; 3: 54-9.

4. Syrjala KL, Artherholt SB, Kurland BF et al. Prospective neurocognitive function over 5 years after allogeneic hematopoietic cell transplantation for cancer survivors compared with matched controls at 5 years. J Clin Oncol 2011; 29: 2397-404

5. Koppelmans V, de Ruiter MB, van der Lijn F et al. Global and focal brain volume in long-term breast cancer survivors exposed to adjuvant chemotherapy. Breast Cancer Res Treat 2012; 132: 1099-106. 6. Ouimet LA, Stewart A, Collins B et al. Measuring neuropsychological change following breast cancer treatment: an analysis of statistical models. J Clin Exp Neuropsychol 2009; 31: 73-89.

7. Loewenstein DA, Acevedo A, Luis C et al. Semantic interference deficits and the detection of mild Alz heimer's disease and mild cognitive impairment without dementia. J Int Neuropsychol Soc 2004: 10: $91-100$.

8. Skaali T, Fosså SD, Andersson S et al. A prospective study of neuropsychological functioning in testicular cancer patients. Ann Oncol 2011: 22 : 1062-70.

9. de Ruiter MB, Reneman L, Boogerd W et al. Cerebral hyporesponsiveness and cognitive impairmen 10 years after chemotherapy for breast cancer. Hum Brain Mapp 2011: 32: 1206-19.

10. Ganz PA, Bower JE, Kwan L et al. Does tumor necrosis factor-alpha (TNF- $\alpha$ ) play a role in postchemotherapy cerebral dysfunction? Brain Behav Immun 2013; 30 (suppl): S99-108.

11. Seigers R, Fardell JE. Neurobiological basis of chemotherapy-induced cognitive impairment a review of rodent research. Neurosci Biobehav Rev 2011; 35: 729-41.

12. Schilder CM, Eggens PC, Seynaeve $C$ et al. Neuro- psychological functioning in postmenopausal breast cancer patients treated with tamoxifen or exemestane after $\mathrm{AC}$-chemotherapy: cross-sectional findings from the neuropsychological TEAMside study. Acta Oncol 2009: 48: 76-85.

13. Batalo M, Nagaiah G, Abraham J. Cognitive dysfunction in postmenopausal breast cancer patients on aromatase inhibitors. Expert Rev Anticancer Ther 2011: 11: 1277-82.

14. Greendale GA, Huang MH, Wight RG et al. Effects of the menopause transition and hormone use on cognitive performance in midlife women. Neurology 2009; 72: 1850-7.

15. Fardell JE, Vardy J, Johnston IN et al. Chemotherapy and cognitive impairment: treatment options. Clin Pharmacol Ther 2011; 90: 366-76.

16. Piras F, Borella E, Incoccia C et al. Evidencebased practice recommendations for memory rehabilitation. Eur J Phys Rehabil Med 2011: 47: 149-75.

17. Hindin SB, Zelinski EM. Extended practice and aerobic exercise interventions benefit untrained cognitive outcomes in older adults: a meta-analysis. J Am Geriatr Soc 2012; 60: 136-41.

Mottatt 5.1. 2013, første revisjon innsendt 10.2. 2013, godkjent 13.5. 2013. Medisinsk redaktør Petter Gjersvik. 